\title{
The Development \& Validation of Social Piety Module to Reduce Moral Degradation for Senior High School Students
}

\author{
Ilham Hamid ${ }^{1, *}$, Syamsul Bachri Thalib ${ }^{1}$, Hamsu Abdul Gani ${ }^{1}$, Marwati $^{2}$ \\ ${ }^{1}$ Postgraduate of Universitas Negeri Makassar, South Sulawesi, Indonesia \\ ${ }^{2}$ IAIM, Sinjai, South Sulawesi, Indonesia
}

Received April 17, 2021; Revised June 15, 2021; Accepted July 19, 2021

\section{Cite This Paper in the following Citation Styles}

(a): [1] Ilham Hamid, Syamsul Bachri Thalib, Hamsu Abdul Gani, "The Development \& Validation of Social Piety Module to Reduce Moral Degradation for Senior High School Students," Universal Journal of Educational Research, Vol. 9, No. 8, pp. 1521 - 1530, 2021. DOI: 10.13189/ujer.2021.090804.

(b): Ilham Hamid, Syamsul Bachri Thalib, Hamsu Abdul Gani (2021). The Development \& Validation of Social Piety Module to Reduce Moral Degradation for Senior High School Students. Universal Journal of Educational Research, 9(8), 1521 - 1530. DOI: 10.13189/ujer.2021.090804.

Copyright $\bigcirc 2021$ by authors, all rights reserved. Authors agree that this article remains permanently open access under the terms of the Creative Commons Attribution License 4.0 International License

\begin{abstract}
Entering the era of the industrial revolution 4.0 , the challenges and problems faced by the world of education worldwide are increasingly complex and complicated. One of these problems is the level of the moral degradation of students, which is increasingly worrying. This research is part of research and development that focuses on the needs analysis, module design, and product validation stages. This study aimed to produce a learning product in the form of a social piety guidance module to reduce the moral degradation of high school students. This research was conducted at SMKN 3 Sinjai, South Sulawesi, Indonesia, by involving three counselling teachers and 15 students in the initial study phase and two experts in the validation phase. Data were collected using several data collection techniques such as (a) interviews, (b) observation, and (c) module validation sheets. The results show that it turns out that a social piety guidance module is needed at the high school level to reduce the level of the moral degradation of students, which is then designed to be a module. From the validation test, information is obtained that the social piety guidance module is proven valid based on experts' judgment with a cumulative average score of 3.53 . Thus, after this module is proven valid, it is recommended that it be tested on users, namely teachers and students.
\end{abstract}

Keywords Social Piety Module, Moral Degradation, Development \& Validation

\section{Introduction}

Before the digital era came as it is today, a common problem that was often encountered in schools, among others, was the deviant behaviour that many students showed. Violent behaviour, bullying, sexual violence, brawl, drinking alcoholic beverages, free sex behaviour, and drug abuse are small parts of schools' problems. Of these deviant behaviours, bullying is one of the most common actions because peers do it. Bullying is seen as a mere aggressive act and a problem related to dynamic social relationships [1]. Bullying can also occur because it is influenced by other factors, such as peers, family, school, and community [2].

Currently, the world has entered a new era that is entirely different from the previous generations. The industrial revolution 4.0 is an era that presents a world without borders. This period is marked by its unique characteristics relating to connectivity, interaction, the development of technological and digital systems, the birth of robots/machines with artificial intelligence capabilities, and the rise of the virtual world around us [3]. However, the three main areas that have occurred sporadic changes in this era are (a) the digital area, (b) the development of biotechnology, and (c) the physical 
aspects such as the development of robots and machines [4]-[6]. The presence of this era did not reduce the level of students' deviant behaviour in schools. Experts then term this condition as a form of moral degradation.

The moral decline for students has occurred both at school and outside of school since the 1950s [7]. However, entering the 20th century until now, the reduction in mortality was allegedly due to the mass media's influence. According to a survey conducted by the Culture and Media Institute, around $74 \%$ of people in America believe that nations worldwide are in a state of moral decline. Another finding states that $64 \%$ believe that the entertainment industry and media have a significant role in this case [7]. This moral change is more often described in the use of language and lifestyle in general. One thing that becomes an important point is that religion does not function appropriately in dealing with this problem [8].

As educational institutions that function to educate children cognitively and affective, schools are still considered unable to overcome these problems. The efforts of guidance and counselling teachers in schools have not been able to reduce student violence significantly [9]. This condition is confirmed by a report from the Indonesian Child Protection Commission in 2016, which states that the number of bullies in schools reaches 93 people [10]. Guidance and counselling have been applied in schools, but many indicators prove that the mismatch of Counselling guidance theory and practise is still being reviewed in schools [11]. One of them is the inadequate counselling system in schools because the conceptualization, implementation, and counselling principles are immature [12], [13].

For that, counsellors' innovative coaching patterns reduce moral degradation so that behavioural deviations can be overcome. Teachers/counsellors can develop models, methods, modules, textbooks, and others in the guidance and counselling process in schools. Several studies take the theme of developing advice and counselling-based learning products. One of them is the development of a module on self-regulation in social relationships [14]. Another study also conducted by Rasmani et al. [15] found that the integrated counseling guidance model developed was proven effective in improving aspects of (a) religious and moral values, (b) physical and motor skills, (c) cognitive, (d) social-emotional, and (e) language \& art. Another study was also conducted by Kurniawan [16] in developing the counseling guidance program in higher education and proved to be valid on experts' judgment.

Of the several research types that these researchers have carried out, there is still no linking social piety in their research's central theme. This social piety is considered essential to be developed because it is deemed necessary to be internalized into the counseling guidance education in schools. For that reason, this study aims to develop and validate a social piety guidance module to reduce the moral degradation of high school students. The formulaic problems in this research are:

1) How is the description of the analysis of the social piety guidance model's needs to reduce the moral degradation of high school students?

2) How is the social piety guidance module's design in reducing the moral degradation of high school students?

3) What is the level of validity of the moral piety guidance module in reducing high school students' moral degradation?

\section{Literature Review}

\subsection{Social Piety}

Social piety comes from two words, namely piety and social. In language, social piety comes from the word "pious", which means obedient and sincere in carrying out worship, being holy, or having faith. Piety can also be defined as obedience or obedience in carrying out worship and an attitude of seriousness to carry out Islam's teachings. On the other hand, the word social relates to society and pays attention to the public interest (helpful, generous, etc.) [17].

Social piety is also defined as piety, which shows people who care about Islamic social values [18]. Social piety is a form of religious orientation in which it is not only related to God but also an individual religious orientation and interactions with fellow humans [19]. Being a pious person is indeed the primary goal of this social piety, but what is more important is the recognition and affirmation of the community towards the constructed social piety [20].

The psychological theory that is close to social piety is the concept of the desire to live meaningfully (the will to meaning) put forward by Viktor Frankl. According to him, conscience is a kind of subconscious spirituality, which is very different from unconscious instincts, as suggested by Sigmund Freud. Another theory that has aspects that have something in common with social piety is prosocial. Prosocial is behaviour that has positive consequences for others [21]. This behaviour refers to individual behaviour consciously in making efforts that are beneficial to the surrounding community [22], [23] which comes from moral cognition, emotion, and value orientation [24].

Furthermore, Miyatake \& Higuchi [25] stated that religious orientation could improve individual prosocial behaviour, fostering mutual helping attitudes and behaviours, various, and others. Prosocial behaviour is also defined as an act of altruism that is selfless or selfless to a helping action that is fully motivated by oneself [26]. Aspects of social piety or prosocial behaviour must be utilized to deal with one of the school problems, namely student behaviour that indicates moral degradation. 


\subsection{Moral Degradation}

The term degradation is defined as the deterioration or setback of something. Moral degradation is a condition where there has been a moral decline, which means that individuals and groups have not obeyed the rules and procedures that apply in society. Moral degradation has become a very controversial issue because society doesn't seem to see this phenomenon. This society has realized and seen for itself the significant decline in matters relating to moral, social and educational values, especially among young people [27]. Many factors influence moral degradation, including (a) the influence of the mass media, (b) defects in the education system, (c) parental behaviour, (d) the influence of gender stigma, (e) economic changes, (f) the desire to self-effacing, and (g) a dirty political system [28].

Another view is put forward by Kartono [29], who states several factors that cause moral degradation, namely the influence of bad environment, weak self-control, and loss of social control. Apart from the factors mentioned above, several views that have also contributed to the increase in moral degradation include (a) the spread of worldly views without spirituality, (b) the magnitude of the influence of a western culture that comes from the increase in information technology, (c) global culture that offers enjoyment pseudo, (d) the level of competition is higher, (e) the community is more individualistic, (f) the family is less able to provide direction, and ( $\mathrm{g}$ ) the number of schools cannot fully control student behaviour, due to limited time, resources and financial resources [30]. Based on this description, it is necessary to take concrete and innovative steps from teachers/counsellors to overcome moral degradation. For example, one of the steps that might be taken is to develop learning products by applying social piety in reducing behaviour that refers to moral degradation.

\subsection{Development \& Validation}

One type of research that has begun to be widely used in education and learning is research and development ( $R$ \& D). This research aims to identify problems in the field, design a product to solve these problems and conduct trials on the product. Research and development always begin with a preliminary study which is usually called the needs analysis phase. This phase seeks to gather product users' information and needs in the field about what they need to improve learning outcomes [31]. After the need's analysis process is complete, the research and development process are continued into the product design phase. This phase consists of several activities in designing the product, from gathering materials to considering module layouts or textbooks.

Another stage in research and development is the validation phase. The validation test aims to determine the product's level of validity based on expert judgment on certain aspects [32]. Thiagarajan et al. [33] stated that there are two types of validation: instructional validation and technical validation. Instructional validation includes several aspects, namely suitability, feasibility, and effectiveness, while technical validation also includes three factors, namely media, format, and language.

\subsection{Module}

One type of learning tool that is widely used today is a module. Learning using modules was first introduced by educators in the United States. The module is an instructional individual that provides intense interaction between students and subject matter. Modules are also defined as short instructional units related to one conceptual unit of subjects [34]. This unit is an independent and independent learning unit focusing on several predetermined goals [35].

Kurniasih [36] states that a module is a set of teaching materials that are presented systematically so that readers can learn the sign of a teacher or facilitator independently. Not much different from this statement, Nasution [37] dan Helaluddin [38] emphasized that the module is an independent learning unit consisting of a series of learning activities designed in a structured and systematic manner to help students achieve learning goals. The use of modules in learning is intended to learn according to their level of ability and speed in learning. Also, students can learn fun because of the module's characteristics, which can cater to different learning styles of students so that they can participate actively.

\section{Method}

\subsection{Research Design, Site, \& Participants}

Based on the formulation of the introduction problem, the research design chosen in this study is research \& development. This research aims to find issues in the field, design products to overcome these problems and test the learning products' quality [39]. Borg \& Gall's design [40] is a research and development theory adopted in this study with ten stages, namely: (a) preliminary study and preliminary information gathering, (b) designing products, (c) designing initial prototypes, (d) testing validation or initial trials, (e) first stage product revisions, (f) limited field trials, (g) second stage product revisions, (h) expanded trials, (i) final product revisions, and (j) dissemination. However, specifically in this article, the stages used are: (a) needing analysis/preliminary study, (b) product design, and (c) validating the development product. 


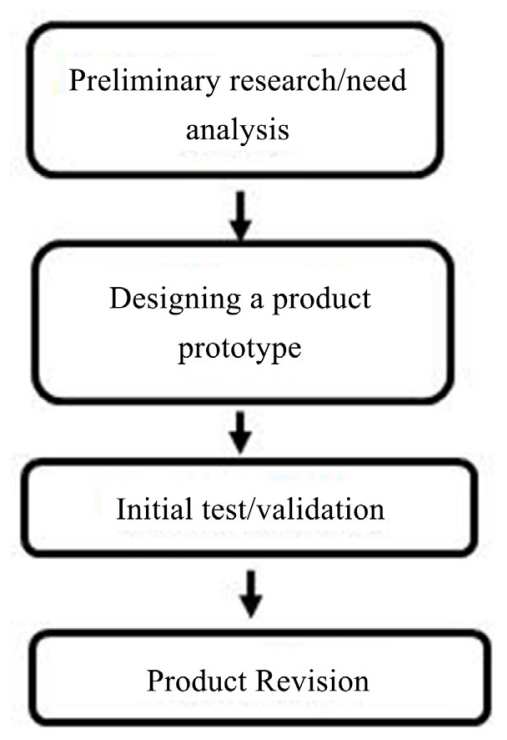

Figure 1. Research \& development flow

The needs analysis phase is the initial phase in this research which aims to obtain an initial description of the conditions and needs of teachers/students regarding guidance and counselling in schools. Researchers carry out this phase by exploring the teacher's perspective-counsellors and students about the problems they face. Interviews are the technique used in collecting data in this preliminary phase.

The second stage is the stage of designing learning products. This stage is carried out by carrying out activities such as designing product layouts, formulating learning objectives, compiling materials, and others. In essence, the product design developed must be adjusted to the results of the needs analysis.

Finally, the next step in this research is to test the validity of the product. The validity test aims to obtain responses and assessments from experts about the quality of the products produced. The experts involved in this stage are two professors from Makassar State University, Indonesia, who have educational backgrounds in guidance and counselling.

Also, this research was conducted at SMK Negeri 3 Sinjai involving two groups of participants. A first group is a group of 3 counsellors/teachers and 15 students from the school and the second group is a group of experts who are competent in the field of guidance and counselling. The 3 counseling guidance teachers involved were research participants who contributed to the preliminary study phase or needs analysis. In contrast, two experts were involved in the validation phase to assess and provide input on products that had been developed. Determination of participants in the study used the purposive sampling technique. This sampling technique selects research participants based on specific considerations determined by the researcher [41] related to the research theme.

\subsection{Data Collection}

This study's data collection was grouped into two parts, namely data collection in the preliminary study phase and the validation test phase. Data collection was carried out in the preliminary study phase using interview techniques, document analysis, and situation analysis at school. Furthermore, in the validation phase, data collection was carried out using a module validation sheet.

\section{a) Semi-structured interviews}

In the early study phase, researchers designed and used semi-structured interviews to interview Counseling Guidance teachers to obtain an initial picture of the student's school condition. Unlike structured interviews, this type of interview does not have rigid rules [42]. That is, its implementation depends on how the interviewee responds to the questions from the researcher.

Compared with standard questionnaires, semi-structured interviews are much better because they can capture participants' perspectives openly [43]. Also, the purpose of using this type of interview is to understand the themes of everyday life from the participant's point of view [44]. In line with this statement, Guthrie [45] stated that semi-structured interviews are used to explore personal experiences in-depth and allow researchers to add questions to the interview as a form of clarification and elaboration.

This study's interview questions were divided into two groups, namely the Counseling Guidance teacher group and the student group. The interview for the Counseling Guidance teacher consists of 10 questions relating to (a) the types of behavioural deviations committed by students, (b) the conditions of guidance and counselling that are currently running in school, and (c) the need for a social piety guidance module. On the other hand, interviews for students consisted of 5 questions relating to: (a) their reasons for committing deviations, (b) what problems they were facing, and (c) what they expected about the social piety guidance being developed.

\section{b) Observation}

One of the data collection techniques in this study is observation. This technique is a qualitative research technique that includes participant observation and ethnography, and field research work [46]. Also, this technique is carried out using a person's senses, especially seeing and hearing systematically \& meaningfully [47]. KatzBuonincontro \& Anderson [48] assert that although it is complex, observation is required by researchers to play several roles using several techniques, including the five senses. In this study, words were made in the preliminary study phase to observe students' activities in school related to their deviant behaviours.

\section{c) Module validation sheet}

In the validation phase, the researcher used the module 
validation sheet to collect data about the validity level of the experts. This validation sheet was developed by researchers tailored to the needs. Some of the aspects assessed in this mode of social piety guidance are (a) usability aspects, (b) feasibility aspects, (c) accuracy aspects, and (d) content/material aspects. This validation sheet is designed by providing four scoring options starting from a score of 1 (lowest) to 4 (highest).

Before being used, the instrument was first tested for the level of validity and reliability. The calculation results show that this instrument has a validity score of 0.78 and a reliability score of 0.88 . Therefore, compared with the categorization of validity \& reliability proposed by Malhotra quoted by Muhali et al. [49], this research instrument is declared valid and reliable. Thus, this instrument is feasible to be used in the process of collecting research data.

\subsection{Data Analysis}

In connection with data analysis in research and development, there are two types of analysis: qualitative and quantitative analysis techniques. Qualitative techniques are used to formulate the first problem related to interviews and observations in the preliminary study phase. Data from interviews \& observations were analyzed qualitatively by using content analysis techniques to find critical points. The content analysis technique is a type of data analysis technique widely used in qualitative research designs. This technique is used to obtain concepts and associations that can be used to explain the data obtained [50]. The content analysis contains three stages in analyzing data, namely: (a) forming a code, (b) grouping the code based on its equation, and (c) data abstraction [51].

Furthermore, the data analysis technique used in the validation phase is quantitative analysis techniques to determine the validity level of the social piety guidance module that has been developed. The results of the experts' assessments are analyzed quantitatively to determine the cumulative mean value. The average score is obtained by adding up the scores from the two experts in each aspect and then dividing them into two. The formula used to calculate the average score is:

$$
\text { Average total score }(\bar{X})=\frac{\sum \bar{A}_{i}}{n}
$$

Information:

$(\bar{X})=$ total mean

$\overline{A_{i}}=$ the average of the its aspect

$n=$ many aspects

After the total average value is obtained, then the score is compared with the category table to see whether the error guidance module is classified as very valid, valid, less valid, or invalid [32]. The validity criteria can be seen in table 1 .
Table 1. The categories of the validity of the learning model

\begin{tabular}{ccc}
\hline No. & Score Range & Category \\
\hline 1. & $3,5 \leq \mathrm{X} \leq 4,0$ & Very Valid \\
2. & $2,6 \leq \mathrm{X}<3,5$ & Valid \\
3. & $1,6 \leq \mathrm{X}<2,5$ & Less valid \\
4. & $1<1,5$ & Unvalid \\
\hline
\end{tabular}

\section{Results}

\subsection{Overview of the Needs Analysis for Social Piety Guidance}

a) The results of the counseling guidance teacher interview

The researchers conducted interviews with counseling guidance teachers/counsellors in schools to get information related to student violations and deviant behaviour. These interview results are used as a basis for developing a product in the form of a guidance module. From the interviews with the counseling guidance teachers at the school, information was obtained that many students were still doing actions or behaviours that were categorized as "moral degradation". There are still many students who are truant, lazy to go to school, often leave class during class hours during the learning process, fighting with school friends, often drink alcoholic drinks, smoke, date, steal light classes, and misbehaving to teachers and friends. This is in line with teacher 1 's statement, which stated: "There are still many deviant student behaviors such as truancy, fighting, fighting, and even being rude to their teachers."

Guidance and counselling services in schools have indeed been implemented for a long time. Besides providing advice and suggestions to students, counseling guidance teachers also offer special treatment for students who behave defiantly at school. But in fact, the guidance program that has been running so far has not had a maximum impact on reducing the number of students who behave defiantly. Teacher 3 explained that: "The guidance program in schools has indeed been running but it has not had a positive impact on students." Furthermore, teacher 1 gave his view that: "The number of students who behave in this way is influenced by many factors and school is not the only factor." This indicates that the social and family environment also has a considerable impact on the student's behaviour.

The three counseling guidance teachers as participants agree that there is a need for innovation in the student guidance process in reducing the moral degradation of these students. Teacher 1 suggested: "It is necessary to make models and patterns of guidance that are relevant to the characteristics of today's students who are very much different from previous generations." In line with this statement, teacher two also suggested: "Counseling guidance teachers must be creative in developing 
guidance models that integrate other aspects, one of which involves aspects of spirituality or religion."

For this reason, the researcher proposes options regarding social piety guidance in reducing student moral degradation. The counseling guidance teachers expressed their agreement on this aspect of social piety because they thought that moral degradation could be suppressed by using this aspect. Teacher 3 mentioned that: "I think social piety is an important aspect in training students in how they should behave and act in the environment in which they live." Likewise, teacher 1 stated: "Social piety is an important aspect of trying to relate religion and how to behave with the social environment."

\section{b) Student Interview Results}

In addition to the counseling guidance teacher, interviews were also conducted with students of class XI SMA to obtain a comprehensive picture of what they experienced to be motivated to take these actions. The 15 students selected for the interview were students who had committed violations based on the counseling guidance teacher's information. Regarding the reasons behind the deviant actions, the participants had various answers. In general, they do these actions because of certain factors, including laziness to learn, being influenced by friends, disliking teachers or specific subjects, etc. Student 10 stated: "I often skipped class because I didn't like the way the teacher taught in a classroom that was stiff and unattractive." In contrast to student 10 , student 5 explained that: "I often skipped classes because my friends invited me to play and I felt bored at school."

In addition to their reasons for committing these deviant actions, the interviews' results also examined the problems they faced at home and school more deeply. Many factors cause their counselling to misbehave, such as having issues with parents or siblings, having conflicts with friends, bullying victims, and so on. As stated by student 5: "I feel annoyed with problems at home, so, even when I was at school, my emotions were still out of control." Also, student 12 explained: "I am skipping school because I feel uncomfortable with my classmates' words and treatment that are offensive."

The third topic in student interviews is related to their needs in the school's guidance and counselling process. Researchers ask what material they need to reduce their deviant actions. Broadly speaking, the materials required in designing a social piety guidance module are:

1. How to cultivate an attitude of tolerance among religious communities?

2. How to be a responsible person?

3. How to be fair?

4. How to cultivate an attitude of empathy?

5. How do you cultivate an orderly attitude?

6. How to demonstrate honesty?

7. How to cultivate trustworthiness or trustworthiness?

c) Observation Result
In line with researchers' direct observations at these schools, there are still many students who experience quite high moral degradation. This is indicated by the existence of several deviant student actions and behaviours. During the observation process, some of the actions/behaviours observed include truancy, laziness, frequent leaving class during the learning process, learning difficulties in certain subjects, fighting with school friends, fighting between schools, drinking alcoholic beverages, stealing, and often not behaving polite to teachers and friends. So, it can be concluded from the need's analysis carried out that the social piety guidance model to reduce moral degradation is not yet available in schools. Thus, it is hoped that it will be implemented immediately to help the supervisor direct students in overcoming their moral degradation.

\subsection{Social Piety Guidance Model Design Overview}

After obtaining information in the preliminary study, the next stage that must be passed is the stage of designing a social piety guidance module. Several things must be prepared in developing the module, namely: (a) type of activity, (b) programmed material, (c) required personnel, (d) procedures, and (e) facilities \& infrastructure. Based on the results of the needs analysis in the preliminary study phase, the materials in the devotional guidance module were developed with the theme of (a) tolerance, (b) responsible personality, (c) fairness, (d) empathy, (e) code of Conduct, (f) honesty, and (g) trustworthy.

The social piety guidance module is designed with several structures, namely:

a) Identity of the material. This section is the initial part of each meeting (each discussion) which contains the identity of the topic, objectives, strategy, time, place of activity, learning resources and materials, and the process of activities.

b) The flow of implementation. This section consists of preparation, delivery/implementation, training, and closing

c) Guidance material

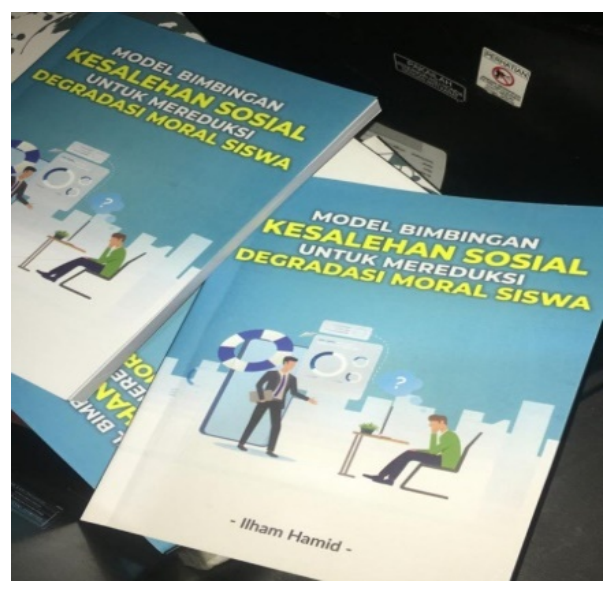

Figure 2. The social piety guidance module 


\subsection{The Level of Validity of the Social Piety Guidance Model}

After the social piety guidance module has been designed, the next step is to test the module's validity. The validity test involves two experts assessing the module based on four main aspects: acceptability, feasibility, accuracy, and content. Specifically, the aspects evaluated in the module are presented in table 2.

Based on the two experts' validity data analysis results, the cumulative average score was 3.53 , and it was categorized as very valid. This can be concluded from the accumulation of the four aspects, including the acceptability aspect of 3.7, the feasibility aspect of 3.5, the accuracy aspect of 3.83, and the content aspect of 3.0. The cumulative average score is then compared with the category table that has been reviewed in the previous method section and is declared very valid. This conclusion is determined based on the criteria, if the cumulative average score is in the range $3.5 \leq \mathrm{M} \leq 4.0$, then this social piety guidance module is declared "very valid".

Table 2. Assessment criteria in the validation test

\begin{tabular}{|c|c|c|}
\hline No & The main aspect & Sub-aspects assessed \\
\hline \multirow{7}{*}{1.} & \multirow{7}{*}{ Acceptability Aspects } & The usefulness of the module for teachers/counselors \\
\hline & & Usefulness of the module for students \\
\hline & & How important is the module for students to reduce module degradation? \\
\hline & & How useful is the module in applying positive ethical and moral values? \\
\hline & & How big is the benefit of the module in shaping students' personalities? \\
\hline & & Does the counselor need to be given an understanding of this module? \\
\hline & & Does the counselor need to implement modules in school? \\
\hline \multirow{6}{*}{2.} & \multirow{6}{*}{ The eligibility aspect } & Does this module have any interest for counselors and students? \\
\hline & & Is the module in accordance with the conditions of students at school? \\
\hline & & Does this module use language that is easy for the counselor and students to understand? \\
\hline & & How much is the relationship between the module and the moral degradation of students in schools? \\
\hline & & Is there clarity in systematics with the material in this module? \\
\hline & & Does the module have a great grip on counselors and students? \\
\hline \multirow{5}{*}{3.} & \multirow{5}{*}{ Aspects of Accuracy } & Is this module following the moral development of students? \\
\hline & & What is the level of conformity between the material and the needs of students? \\
\hline & & How is the clarity of the values in the module to reduce students' moral degradation? \\
\hline & & Does this module require supporting media to make it more attractive to counselors and students? \\
\hline & & Does this module need evaluation and reflection on each material for students? \\
\hline \multirow{5}{*}{4.} & \multirow{5}{*}{ Content Aspects } & How is the suitability of the use of guidance services with the content of the module material? \\
\hline & & How to clarify the content of the module material to reduce student moral degradation? \\
\hline & & How is the suitability of the module material content to reduce student moral degradation? \\
\hline & & How is the clarity of the objectives of the module material content to reduce student moral degradation? \\
\hline & & How the benefits of module material content are associated with students' moral development tasks? \\
\hline
\end{tabular}

Table 3. Effectiveness test results

\begin{tabular}{cccc}
\hline No & The assessment aspect & Average (2 experts) & Category \\
\hline 1. & Acceptability & 3.7 & Very valid \\
2. & Eligibility & 3.5 & Very valid \\
3. & Accuracy & 3.83 & Very valid \\
4. & Content & 3 & Valid \\
\hline
\end{tabular}




\section{Discussion}

Based on the analysis of needs through interviews and observations, many students commit deviant actions that fall into the category of moral degradation in schools. Many students' behaviours violate rules and harm others, such as direct or online bullying, fighting, brawl, etc. In line with these findings, Samson \& Allida [7] stated that the majority of moral changes among students are marked by language and the student's lifestyle. Students tend to imitate what they see both in the environment and from the media. Okoth [8] states that students think that the only way to solve the problems they face is war, lies, cheating, theft, corruption, greed, etc.

This problem must be addressed immediately because all forms of moral degradation have a significant effect on students' psychological development. One form of moral degradation is violence perpetrated by peers. A study states that there is a relationship between peer violence and internal problems, one of which is the level of anxiety of high school students [52]. Furthermore, other studies also claim that there is a significant relationship between students' previous experiences of violence and their peers at school and their current anxiety symptoms [53]. The effects of bullying even affect someone who has reached adulthood even though the experience occurred during childhood [54]. Thus, it is necessary to develop guidance and counselling modules in reducing the moral degradation of these students [55]. Thus, it is necessary to develop guidance and counselling modules in reducing the moral degradation of these students.

Innovations in designing guidance and counselling modules need to be integrated with other aspects, one of which is social piety. This aspect has a meaning close to prosocial theory because the focal point is on the ability to behave in a person towards his environment, which is associated with his spiritual aspect. In this study, the learning tool developed in the form of a guidance module to allow students to learn independently and according to their learning style. Students in their learning process can use the module without the teacher or facilitator's help [56]. For that reason, a module must be developed incoherent and clear systematics and use language appropriate to high school student's level of development [57].

In testing the level of product quality that has been developed, the researcher conducts a validation test involving several experts in the field of guidance and counselling. This validity test is intended to determine the extent of the social piety guidance module's validity based on expert assessments. From the results of the validation test, it was obtained a cumulative average score of 3.53 and was categorized as "very valid". The validation process is essential because it is rational and logical. In addition to being logical, validation can also describe estimates of how many sizes or dimensions represent each hypothesis [58]. Thus, if this module's validation is declared valid, it means that the product can be tested on users, either teachers or students.

\section{Conclusions}

This study includes several stages in research and development ( $R \& D$ ), which consist of: (a) preliminary study/needs analysis, (b) product design, and (c) testing the validity of the product. Based on the preliminary study results, it can be concluded that the moral degradation of students in schools, especially SMK Negeri 3 Sinjai, South Sulawesi, Indonesia, is still common. Various behaviours that reflect this moral degradation include truancy, frequently leaving class during learning, fighting, bullying, etc. This condition requires a solution so that the level of students' moral degradation can be reduced. One of them is by developing a social piety guidance module aimed at high school students. After the module has been designed, the validity test is then carried out involving experts. The validation results show that the social piety development module to reduce students' moral degradation is proven valid by obtaining a cumulative average score of 3.53 and is categorized as very valid. Thus, this module can be continued for testing activities with users, both teachers and students.

\section{Acknowledgements}

The author would like to thank SMK Negeri 3 Sinjai, South Sulawesi and Makassar State University for supporting the implementation of this research.

\section{REFERENCES}

[1] A. Fullchange and M.J. Furlong, “an Exploration of Effects of Bullying Victimization from Complete Mental Health Perspective," SAGE Open, pp. 1-12, 2016. https:doi.org/10.1177/2158244015623593

[2] H.K. Al-Raqqad, E.S. Al-Bourini, F.M. Al-Talahin and R.M.E. Aranki, "The Impact of School Bullying on Students' Academic Achievement from Teachers Point of View," International Education Studies, vol. 10, no. 6, pp. $44-50,2017$. https://doi.org/10.5539/ies.v10n6p44

[3] H. Helaluddin, "Redesain Kurikulum Pendidikan Tinggi Islam: Strategi dalam Menyongsong Era Revolusi Industri 4.0," Jurnal Mudarrisuna: Media Kajian Pendidikan Agama Islam, vol. 8, no. 2, pp. 258-277, 2018. https://doi.org/10.22373/jm.v8i2.3224

[4] H. V. Thai and M. A. Anh, "The 4.0 Industrial Revolution Affecting Higher Education Organizations' Operation in Vietnam," International Journal of Management Technology, vol. 4, no. 2, pp. 1-12, 2017. 
[5] B. Lavanya, B. S. Shylaja, and M. S. Santosh, "Industry 4.0-the Fourth Industrial Revolution," International Journal of Science, Engineering \& Technology Research, vol. 6 , no. 6, pp. 1004-1006, 2017.

[6] A. Rojko, "Industry 4.0 Concept: Background and Overview," International Journal of Interactive Mobile, vol. 11, no. 5, pp. 77-90, 2017.

[7] B. Samson and V. Allida, "Moral Decline in Schools: Reflections on Public Secondary Schools in Iganga District, Uganda," Baraton Interdiscilonary Research Journal, vol. 8, no. Special Issue, pp. 1-9, 2018.

[8] J. O. Okoth, The Root cause of Moral Decay in Uganda. Uganda: New Vision, 2013

[9] A. Jan and S. Husain, "Bullying in Elementary Schools: Its Causes and Effects on Students," Journal of Education and Practice, vol. 6, no. 19, pp. 46-57, 2015.

[10] K. Kartika, H. Darmayanti, and F. Kuriawati, "Fenomena Bullying di Sekolah: Apa dan Bagaimana?," Pedagogia Jurnal Ilmu Pendidikan, vol. 17, no. 1, pp. 55-66, 2019. https://doi.org/10.17509/pdgia.v17i1

[11] [11] B. M. Kanga, V. K. Nyaga, and H. K. Barchok, "Effectiveness of Guidance and Counseling Services in Enhancing Students' Adjustment to School Physical Environment in Public Boarding Secondary Schools in Kenya," International Journal Education and Research, vol. 3, no. 7, pp. 201-212, 2015.

[12] W. J. Mau and J. Li, "Transforming High School Counseling: Counselors' Roles, Practices, and Expectations for Students' Succes," Administrative Issues Journal: Connecting Education, Practice, and Research, vol. 6, no. 2, pp. 83—95, 2016. https:doi.org/10.5929/2016.6.2

[13] H. Sakiz and M. Saricali, "Paradigmatic Challenges in School Counselling: Correlates and Reflections on Practice," Journal of Psychologists and Conseullors in School, vol. 29, pp. 69-81, 2019. https://doi.org/10.1017/jgc.2018.23

[14] I. K. Bancin, M. Mudjiran, and R. Rusdinal, "Development of Guidance and Counseling Module on Self-regulation of Students in Social Relations," Journal of Counseling and Educational Technology, vol. 2, no. 1, pp. 6-11, 2019. https://doi.org/10.32698/0341

[15] U. E. E. Rasmani, S. Wahyuningsih, A. R. Pudyaningtyas, and N. E. Nurjanah, "Development of An Integrated Guidance Counseling Model for Early Childhood Education Learning Programs," in The 2nd International Conference on Science, Matthematics, Environtment, and Education, 2019, vol. 2194.

[16] F. Kurniawan, "Developing of Annual Program Guidance and Counseling in Higher Education," COUNS-EDU: The International Journal of Counselling and Education, vol. 3, no. 3, pp. 108-114, 2018. https://doi.org/10. 23916/0020180317130

[17] R. Z. Falah, "Membentuk Kesalehan Individual dan Sosial melalui Konseling Multikultural," Konseling Religi: Jurnal Bimbingan Konseling Islam, vol. 7, no, 1, pp. 163-188, 2016.

[18] M. Rozikin, “Analisis Pengukuran Kinerja Kesalehan Sosial Provinsi Jawa Timur," Jurnal Ppkn, vol. 5, no. 2, 2017.
[19] M. Muzammil, "Indeks Kesalehan Sosial Masyarakat Kabupaten Madiun Tahun 2019," Birokrasi Pancasila: Jurnal Pemerintahan, Pengembagunan dan Inovasi Daerah, vol. 2, no. 1, pp. 32-38, 2020.

[20] I. Istiqomah, "Validitas Konstruk Alat Ukur Kesalehan Sosial," Jurnal Ilmu Psikologi Terapan, vol. 07, no. 01, pp. 119-131, 2019.

[21] N. Klein, "Prosocial Behavior Increases Perceptions of Meaning in Life," The Journal of Positive Psychology, pp. $1-8$, 2016. https://doi.org/10.1080/17439760.2016.1209541

[22] U. Toseeb, A. Pickles, K. Durkin, N. Botting, and G. Conti-Ramsden, "Prosociality from Early Adolescence to Young Adulthood: A Longitudinal Study of Individuals with A History of Language Impairment," Research in Developmental Disabilities, vol. 62, pp. 148-159, 2017. https:doi.org/10.1016/j.ridd.2017.01,018

[23] M. J. O. Baron, I. E. Bilbao, P. A. Urquijo, S. C. Lopez, and A. P. Jimeno, "Moral Emotions Associated with Prosocial and Antisocial Behavior in School-aged Children," Psicothema, vol. 30, no. 1, pp. 82-88, 2018. https://doi.org/10.7334/psicothema2016.143

[24] Y. Guo, "The Influence of Social Support on the Prosocial Behavior of College Students: The Mediating Effect Based on Interpersonal Trust," English Language Teaching, vol. 10, no. 12, pp. 158-163, 2017. https://doi.org/ $10.5539 /$ elt.v10n $12 \mathrm{p} 158$

[25] S. Miyatake and M. Higuchi, "Does Religigous Priming Increase the Prosocial Behaviour of Javanese Sample in An Anonymous of Social Psychology," Asian Journal of Social Psychology, vol. 20, no. 1, pp. 54-59, 2017. https://doi.org/10.1111/ajsp.12164

[26] E. Egilmez and J. Naylor-Tincknell, "Altruism and Popularity," International Journal of Educational Methodology, vol. 3, no. 2, pp. 65-74, 2017. https://doi.org/10.12973/ijem.3.2.065

[27] N. C. Njoku, “Teachers' Perception on the Dimensions of Moral Decadence among Secondary School Students in Ebonyi State, Nigeria," Journal of Education \& Practice, vol. 7, no. 26, pp. 187-191, 2016.

[28] K. Bhakta and N. Dutta, "Degradation of Moral and Ethical Values Among Indian Youths: An Emerging Issue," International J.ournal of Innovative Research in Multidisciplinary Field, vol. 3, no. 6, pp. 336-340, 2017.

[29] K. Kartono, Patologi Sosial Kenakalan Remaja. Jakarta, Indonesia: Raja Grafindo, 2013.

[30] S. Muthohar, "Antisipasi Degradasi Moral di Era Global," Jurnal Pendidikan Islam, vol. 7, no. 2, 2013.

[31] H. Helaluddin, "Analisis Kebutuhan dalam Redesain Silabus (RPS) Mata Kuliah Bahasa Indonesia di Perguruan Tinggi," Jurnal Gramatika: Jurnal Penelitian Pendidikan Bahasa, vol. 4, no. 1, pp. 85-104, 2018.

[32] T. Supartini, I. T. J. Weismann, H. Wijaya, and H. Helaluddin, "Development of Learning Methods through Songs and Movements to Improve Children's Cognitive and Psychomotor Aspects," European Journal of Educational Research, vol. 9, no. 4, pp. 1615-1633, 2020. https://doi.org/10.12973/eu-jer.9.4.1615 
[33] S. Thiagarajan, D. S. Semmel, and M. I. Semmel, Instructional Development for Training Teachers of Exceptional Children. Blomington Indiana: Indiana University, 1974.

[34] P. V Padmapriya, "Effectiveness of Self Learning Modules on Achievement in Biology among Secondary School Students," International Journal of Education and Psychological Research, vol. 4, no. 2, pp. 44-46, 2015.

[35] A. D. Yazon, "Validation and Effectiveness of Module in Assessment of Students Learning," International Journal of Science and Research, vol. 7, no. 11, pp. 1833-1836, 2018.

[36] S. Kurniasih, Sukses Mengimplementasikan Kurikulum 2013. Surabaya: Kata Pena, 2014.

[37] N. Nasution, Berbagai Pendekatan dalam Proses Belajar Mengajar. Jakarta: Bumi Aksara, 2015.

[38] H. Helaluddin, "Pengembangan Modul Mata Kuliah Pengembangan Kepribadian (MPK) Bahasa Indonesia Fakutas Pertanian Universitas Muhammadiyah Palembang," Jurnal Global Expert, vol. 3, no. 1, 2014.

[39] H. Helaluddin, S. V. N. Rante, and H. Tulak, Penelitian \& Pengembangan: Sebuah Tinjauan Teori dan Praktik dalam Bidang Pendidikan. Serang: Media Madani, 2020.

[40] W. R. Borg and D. M. Gall, Educational Research. New York: Longman, 1989

[41] H. Helaluddin and H. Wijaya, Analisis Data Kualitatif: Sebuah Tinjauan Teori \& Praaktik. Makassar: Sekolah Tinggi Filsafat Jaffray, 2019.

[42] E. A. R. Adhabi and C. B. L. Anozie, "Literature Review for the Type of Interview in Qualitative Research," International Journal of Education, vol. 9, no. 3, pp. 86-97, 2017. https://doi.org/10.5296/ije.v9i3.11483

[43] K. Al Balushi, "The Use of Online Semi-structured Interviews in Interpretive Research," International Journal of Science and Research, vol. 7, no. 4, pp. 726-732, 2018. https://doi.org/10.21275/ART20181393

[44] S. Kvale and S. Brinkman, Interviews: Learning the Craft of Qualitative Research Interviewing. London: Sage, 2009.

[45] K. H. Guthrie, "Nothing is Ever Easy': Parent Perceptions of Intensity in Their Gifted Adolescent Children," The Qualitative Report, vol. 24, no. 8, pp. 2080-2101, 2019.

[46] S. Jamshed, "Qualitative Research Method-interviewing and Observation," Journal of Basic and Clinical Pharmacy, vol. 5, no. 4, pp. 87-88, 2014. https://doi.org/10.4103/0976-0105.141942

[47] B. Smit and A. J. Onwuegbuzie, "Observations in Qualitative Inquiry: When What You See is Not What You See," International Journal of Qualitative Methods, vol. 17, pp. 1-3, 2018. https://doi.org/10.1177/1609 406918816766

[48] J. Katz-Buonincontro and R. C. Anderson, "A Review of
Articles Using Observation Methods to Study Creativity in Education (1980-2018)," Journal of Creative Behavior, pp. $1-17,2018$. https://doi.org/10 .1002/jocb.385

[49] M. Muhali, L. Yuanita, and M. Ibrahim, "The Validity and Effectiveness of The Reflective-Metacognitive Learning Model in Improving Students' Metacognitive Ability in Indonesia," Malaysian Journal of Learning and Instruction, vol. 16, no. 2, pp. 33-74, 2019.

[50] S. Yildiz and S. Gizir, "A Phenomenological Study of the Perceptions of Candidate Teachers about The Concepts of School, Teacher and Student in Their Dreams," International Journal of Instruction, vol. 11, no. 2, pp. 309324, 2018. https://doi.org/10.12973/iji.2018.11221a

[51] H. Helaluddin, S. Syawal, N. Nurmadiah, and Z. Zulfah, "The Perception and Expectation of University Students as Generation Z: A Qualitative Study about Learning Scenario," in Teacher Education and Professional Development in Industry 4.0: Proceedings of the 4th International Conference on Teacher Education and Professional Development (InCoTEPD 2019), 2020.

[52] J. Corboz, O. Hemat, W. Siddiq, and R. Jewkes, "Children's Peer Violence Perpetration and Victimization: Prevalence and Associated Factors among School Childreen in Afghanistan," PLoS ONE, vol. 13, no. 2, pp. 1-16, 2018. https:doi.org/10.1371/journal.pone.0192768.

[53] D. L. Espelage, J. S. Hong, and S. Mebane, "Recollections of Childhood Bullying and Multiple Forms of Victimization: Correlates with Psychological Functioning among College Students," Social Psychology Performance, vol. 9, no. 4, pp. 715-728, 2016.

[54] L. Arseneault, "Annual Research Review: The Persistent and Pervasive Impact of Being Bullied in Childhood and Adolescence: Implications for Policy and Practice, "The Journal of Child Psychology and Psychiatry, vol. 59, no. 4, pp. $405-421,2017$. https://doi.org/10.1111/jcpp.12841

[55] S. T. Lereya, W. E. Copeland, E. J. Costello, and D. Wolke, "Adult Mental Health Consequences of Peer Bullying and Maltreatment in Childhood: Two Cohort in Two Countries," Lancet Psychiatry, vol. 2, pp. 524-531, 2015. https://doi.org/10.1016/s2215-0366(15)00165-0

[56] C. M. Ambayon, "Modular-based Approach and Students' Achievement in Literature," International Journal of Education and Literacy Studies, vol. 8, no. 3, pp. 32-36, 2020. https://doi.org/10.7575/aiac.ijels.v.8n.3p.32

[57] N. S. Reznani, N. Nurhayati, and S. Soetopo, "Pengembangan Bahan Ajar Mata Kuliah Menyimak Berbasis Kearifan Lokal," Jurnal Penelitian Pendidikan Bahasa dan Sastra, vol. 6, no 1, pp. 42-50, 2021. https://doi.org/10.32096/jp2bs.v6i1.642

[58] B. Ramaiah, S. Sharma, S. Poudel, and R. Koneri, "Development and Validation of An Instrument to Enhance the Community Pharmacy Practitioner's Knowledge towards Handling of High Risk/Alert Medications," Global Journal of Medical Research, vol. 19, no. 1, 2019. 